\title{
The endangered Arctic fox in Norway-the failure and success of captive breeding and reintroduction
}

\author{
Arild Landaa, Øystein Flagstad ${ }^{a}$, Veronika Areskoug ${ }^{b}$, John D. C. Linnella, Olav Strand ${ }^{a}$, \\ Kristine Roaldsnes Ulvund ${ }^{a}$, Anne-Mathilde Thierry ${ }^{a}$, Lars Rød-Eriksen ${ }^{a} \&$ Nina E. Eide ${ }^{a}$
}

aTerrestrial Division, Norwegian Institute for Nature Research, Trondheim, Norway; ${ }^{b}$ Centre for Ecological and Evolutionary Synthesis, Department of Biosciences, University of Oslo, Oslo, Norway

\begin{abstract}
The Arctic fox (Vulpes lagopus L.) is listed as extinct in Finland, endangered in Sweden and critically endangered in Norway. Around 2000 there were only 40-60 adult individuals left, prompting the implementation of conservation actions, including a captive breeding programme founded from wild-caught pups. The initial breeding trials failed, probably because of stress among captive animals, and the programme was radically changed in 2005. Eight large enclosures within the species' historical natural habitat were established, which had the positive effect of all pairs breeding in 2007. As of 2015, 385 pups (yearly average 37) were produced. In this ongoing programme, pups are released the winter (January-February) following their birth and have had an average first-year survival of 0.44 . The release sites are prepared with artificial dens and a network of supplementary food dispensers, designed to work exclusively for the Arctic fox. After just four to seven years of releases, populations have been effectively re-established in three mountain areas where the species had been locally extinct. One of the newly re-established populations has become the largest population in Norway. Several other populations, including Swedish ones, have benefited considerably from successful immigration of released foxes. The number of wild-born pups that are descendants of released foxes has likely exceeded 600, and in $201450 \%$ of all free-living breeding pairs in mainland Norway included released foxes or their descendants. The Norwegian Arctic fox captive breeding programme has proven to be an important conservation action for the recovery of the Scandinavian Arctic fox population.
\end{abstract}

\section{KEYWORDS}

Vulpes lagopus L; climate change; conservation actions; survival; lemming cycles; red fox competition

\section{Introduction}

During the last centuries many carnivore species have experienced severe population decline with an increased risk for extinction (Woodroffe 2001), which is also true for the Arctic fox (Vulpes lagopus) in Fennoscandia. As a consequence of shrinking Arctic and alpine habitats, red fox expansion and interruptions in rodent cycles, the Arctic fox was in 2009 classified by the IUCN as one of 10 flagship species as indicators for ongoing climate change impacts (IUCN 2009). Although still abundant in most parts of its distribution range, the situation for the Arctic fox in Fennoscandia is grave, already classified as extinct in Finland, critically endangered in Norway (Wiig et al. 2015) and endangered in Sweden.

The historic Arctic fox population in Fennoscandia probably comprised 10000-20000 foxes, but declined dramatically during the late 1800s and early 1900s (Collett 1912; Tannerfeldt \& Angerbjörn 1998). This initial decline was most likely caused by overharvest, due to the high value of its fur (Lönnberg 1927; Østbye et al. 1978; Linnell et al.
1999). The Arctic fox was protected by law in 1928 in Sweden, 1930 in Norway and 1940 in Finland. By the end of the 20th century, more than 70 years after the species was protected, there were no signs of natural recovery; in fact, there had been a continued decline, with several subpopulations becoming locally extinct (Herfindal et al. 2010). In 2000, there were as few as 40-60 adult individuals left in Scandinavia, scattered widely across the peninsula (Angerbjörn et al. 2013).

With this very low population size, the likelihood of complete extirpation in Scandinavia was quite high (Linnell et al. 1999; Loison et al. 2001). Loison et al. (2001) demonstrated that the very low Arctic fox population was sensitive to variation in both demography, environmental change and occasional disease outbreaks. They also suggested that the Arctic fox population could be suffering from Allee effects, i.e., positive density dependence (Ceballos \& Ehrlich 2002). The increasing fragmentation of the remnant populations was accompanied by a $25 \%$ loss of genetic diversity over the last 100 years, and at the start of this millennium the Scandinavian Arctic fox population was split into four relatively isolated sub- 
populations (Dalén et al. 2006). In addition to the obvious risk of dropping below viable population size over time, there was consensus that the range expansion and increase in red fox (Vulpes vulpes) population size as well as the interrupted lemming cycles were major threats, challenging Arctic fox recovery and conservation (Angerbjörn et al. 2013).

Several conservation measures were implemented to rescue the Scandinavian Arctic fox from regional extinction, including supplementary feeding to increase survival and reproduction and red fox control to reduce competition and intraguild interactions (Angerbjörn et al. 2013). Population supplementation and reintroduction was also considered necessary in order to restore connectivity and reduce the risks of Allee effects and inbreeding depression (Linnell et al. 1999). As a direct response, the Norwegian Environment Agency funded the Arctic Fox Captive Breeding Programme, with the goal of strengthening extant populations and reintroducing the species to areas from which it had gone extinct.

Many studies have demonstrated that the translocation of wild-caught individuals from a healthy population is an effective way of supplementing a threatened population or reintroducing a species back to an area from which it has vanished (Slough 1994; Smith \& Clark 1994; Servheen et al. 1995). Despite problems of post-release movements and homing behaviour (Davis 1983; Slough 1989; Linnell et al. 1997), translocated carnivores generally have high survival (Fritts et al. 1985; Carbyn et al. 1994; Jule et al. 2008). However, within Fennoscandia, there was no single ideal source of wild Arctic foxes for translocation. None of the relict populations was large enough to donate a sufficient number of adult foxes. Furthermore, genetic studies had revealed a clear difference between the foxes on the Scandinavian peninsula and those from the closest large populations in Svalbard and the Kola and Taimyr regions of Siberia (Dalén et al. 2002; Dalén et al. 2006). Another issue was rabies, which is present in Siberia and Svalbard (Prestrud et al. 1992; Griffith \& Scott 1993; Mørk \& Prestrud 2001), whereas mainland Norway and Sweden are rabiesfree.

Although reintroduction of animals from captive breeding is not the best option (Griffith et al. 1989), it has been used successfully for many species (Jefferies et al. 1986; Phillips \& Parker 1988; Kleiman 1989; Stanley Price 1989; Beck et al. 1994; Carbyn et al. 1994; Ginsberg 1994; Soderquist \& Serena 1994; Phillips et al. 1995). Indeed, these studies have given important baseline information for captive breeding, but there is always a need for species- and site-specific adjustment of breeding and release methodology. A step in the right direction is the programme on which we report here: Arctic foxes bred in large enclosures in their natural habitat and juveniles released at sites with artificial dens and year-round supplementary feeding using customized food dispensers.

Here, we describe the initial failures and later success of the Arctic Fox Captive Breeding Programme, which was initiated in 2000. We describe and analyse the three main parts of the breeding programme: (1) the captive breeding station and its design; (2) release methods and support under release; and (3) establishment, reproduction and survival.

\section{Methods}

\section{Breeding stock}

At the start of this project there were no disease-free captive Arctic foxes of wild origin in any zoos in Fennoscandia; founding animals had to be taken from the remnant wild populations. Although the remnant populations were critically small, the natural mortality of Arctic fox pups is very high (Garrott \& Eberhardt 1982; Tannerfeldt \& Angerbjörn 1996; Loison et al. 2001; Meijer et al. 2008). Therefore, removing a small number of pups from wherever reproduction occurred in Norway was judged to have a small negative effect on the donor populations (Linnell et al. 1999).

We took a maximum of one pup from small litters (three to four pups) and two pups from larger litters (five or more pups). The intention was to take pups as close to weaning (six to eight weeks of age) as possible in order to increase the possibilities of habituating them to captivity as well as increasing the benefit of reduced intra-litter competition for the remaining siblings. Where two pups were taken, they were of opposite sex, and wherever possible the smallest pups were captured. We did not observe den relocations or changed behaviour among resident parents as a result of capturing efforts or pup removal. After achieving successful breeding in captivity, we recruited breeding animals from our own breeding stock when possible after assessing genetic and habituation issues described later (Table 1).

\section{Initial captive breeding set-up}

In 2001 six pups were caught, followed by two more in 2002. These represented the extant populations in Finse, Børgefjell, Saltfjellet and Finnmark (Fig. 1). On account of budget constraints in the early years of the programme and previous experiences in Sweden, where Arctic foxes kept in natural enclosures died (Widén et al. 2012), all animals were initially housed in a modified fox farming set-up consisting of rows with raised double netting cages $\left(1.6 \mathrm{~m}^{2}\right)$ exposed to elements on all 
Table 1. The number of Arctic fox pups captured in the wild as potential breeding recruits to the captive breeding programme during 2001-2015. Recruitment of breeders from our own stock is also given.

\begin{tabular}{|c|c|c|c|c|c|c|c|c|c|c|c|c|c|c|c|}
\hline \multirow[b]{2}{*}{ Mountain area } & \multicolumn{15}{|c|}{ Year } \\
\hline & 01 & 02 & 03 & 04 & 05 & 06 & 07 & 08 & 09 & 10 & 11 & 12 & 13 & 14 & 15 \\
\hline Finse $^{a}$ & 3 & 1 & & & & & & & & & & & & & \\
\hline Snøhetta & & & & & & & & & & & 1 & & & & \\
\hline Knutshø & & & & & & & & & & & & & 1 & 1 & \\
\hline Helags & & & & & & & & 2 & & & & & & & \\
\hline Blåfjellet & & & & 1 & & & & & & & & & 1 & & \\
\hline Børgefjell & 1 & & & 3 & 2 & & & & & & & & & & \\
\hline Saltfjellet & 2 & & & & 1 & & 1 & & & & & & 1 & 1 & 1 \\
\hline Indre Troms & & & & & 1 & & & & & & & & & & 2 \\
\hline Reisa Nord & & & & & 1 & & 1 & & & & & & & & \\
\hline Porsanger Vest & & & & & & & 1 & & & & & & & & \\
\hline Varangerhalvøya & & 1 & & & & & & & & & & & & & \\
\hline Own breeding & & & & & & 4 & 4 & & 1 & 1 & 1 & 4 & 2 & 2 & 2 \\
\hline Total & 6 & 2 & 0 & 4 & 5 & 4 & 7 & 2 & 1 & 1 & 2 & 4 & 5 & 4 & 5 \\
\hline
\end{tabular}

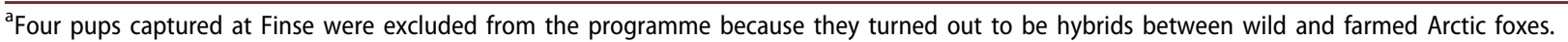

sides with common roofing at the Dal Experimental Animal Station, Norwegian Veterinary University. In early 2004 we moved one pair to a large (15 da) natural habitat enclosure at Langedrag Familiepark (a zoo, now called Langedrag Naturpark) and the rest of the captive stock to the facilities of experienced local farmers (double raised netting cages). Concurrently, planning and fund-raising for a breeding station in a natural alpine fox habitat started. Also in 2004, the project established an advisory group with representatives from the various veterinary environments in Norway (including those working with farm foxes) and ecologists working on high alpine ecology and Arctic foxes (University of Tromsø and University of Stockholm).

\section{Establishment of enclosures and breeding facilities in a natural habitat}

During planning and construction of the breeding facilities and when developing handling protocols we drew upon the experience from other similar captive breeding programmes and the fox fur industry, as well as advice from animal welfare experts. In particular, we studied the island fox (Urocyon littoralis sp.) and swift fox (Vulpes velox) captive breeding and reintroduction programmes (Smeeton 1994; Smeeton et al. 2003; Coonan et al. 2005). We then adapted these models to fit the specifics of Arctic fox biology when designing enclosure size, piles of boulders for play and hiding and artificial dens.

The breeding facilities were established in 2005 at Sæterfjellet in Oppdal Municipality in a natural Arctic fox habitat (1380 m asl). Eight enclosures approximately $50 \mathrm{~m} \times 50 \mathrm{~m}(2.5 \mathrm{da})$ in size were constructed for breeding and one smaller enclosure $(20 \mathrm{~m} \times 20 \mathrm{~m})$ for soft release trials (Supplementary Fig. S1). The enclosures were constructed with fences $4.5 \mathrm{~m}$ in height and with a $40 \mathrm{~cm}$ overhang angled $45^{\circ}$ inwards at the top. Challenges that arose during some winters included deep snow accumulation caused by the high fences, which was solved by building a large snow fence and increasing the distance between the exposed enclosures.
The facilities were designed to maximize the wellbeing of the animals. Within each enclosure housing one female and one male, there was a minimum of two artificial dens manufactured in fibreglass, insulated with a $1.5 \mathrm{~cm}$ thick sandwich core (Fig. 2a). Inside each den there was a wooden box with a polystyrene insulated bottom, identical to what is used in the fox farming industry (Fig. 2b). In addition, several rock piles made of small and large rocks served as hiding and play facilities.

The foxes were given standard fox food manufactured for the fox farming industry as well as meat from road kills of muskox (Ovibos moschatus), reindeer (Rangifer tarandus), moose (Alces alces), red deer (Cervus elaphus) and roe deer (Capreolus capreolus). During summer the animals were fed each day, and in winter a minimum of five times a week. The animals were regularly treated for intestinal parasites using commercial medicine for small dogs (Milbemax tablets, containing $2.5 \mathrm{mg}$ Milbemycinoksim and $25 \mathrm{mg}$ Prazikvantel).

In addition, each enclosure was equipped with one feeding dispenser with dry dog food pellets, ensuring that the animals have had access to food in case of long periods with extreme weather that prevented normal tending. The feeding dispensers also served to habituate the pups to the feeders that they would later encounter close to the release sites. The feeding dispenser was constructed by mounting two vertical barrels at the end of a horizontal barrel (120 litre Noreko polyester barrels). A PVC tube with an inside diameter of $125 \mathrm{~mm}$ was attached to the entrance, which prevented larger species like red foxes and wolverines (Gulo gulo), as well as scavenging birds (corvids), from entering the feeding chamber. The connections between barrels were reinforced using $21 \mathrm{~mm}$ waterproof plywood. Water from snowmelt and condensation drained through holes drilled through the bottom of the container (Fig. 2c).

In addition to the enclosures, a building similar in design to the housing used in the fox farm industry (standard wire cages raised from the ground) held up to six pairs of foxes when it was necessary to keep 
animals under controlled conditions (e.g., for medical treatment and during periods of high escape risk due to snow accumulation). An administration building comprised video monitoring facilities, a day room, WC, storage space and a bedroom.

Fox behaviour was followed with video surveillance. A camera was installed in each of the artificial denning boxes (Fig. 2b). The cameras had a $2.3-2.9 \mathrm{~mm}$ wideangle lens and were infrared sensitive, $1 / 3$ inch charged-couple devices with 570 lines resolution and light sensitivity at 0.003 Lux. One light emitting diode with a wavelength of $850 \mathrm{Nm}$ illuminated the boxes. Ten of the cameras $(2.0 \mathrm{~mm})$ had a passive built-in twister pair transmitter, enabling video signals to be transmitted on a twin cable. The cabling was reinforced with thick plastic tubes to withstand chewing by foxes both outside and inside the enclosures. One picture per 1-2 seconds from each of the cameras was automatically saved. The surveillance system was available on screen in the administration building. Feeds from four of the cameras were available online to the public (http://www.nina.no/Våre-fagområder/Arter/ Fjellrev/Avlsprogrammet-for-fjellrev).

Each animal was assigned a unique identification number. All events from birth, such as partner, breeding and number of pups, as well as any handling or treatment, including weights and collected samples, were recorded for each animal. All pups produced in captivity were marked with Dalton Rototag plastic ear tags in both ears (Dalton Continental BV). The colour and number combinations were unique for each animal and were coordinated with Arctic fox marking in Sweden. A Biomark passive pit tag was implanted underneath the skin of the neck. For trapping we used $32 \times 10 \times 2$ inch Tomahawk professional raccoon/feral cat live traps. In addition, a DNA sample (small piece of tissue) was taken from every individual. Pups released during 2007-09 (37 individuals) were equipped with VHF radio transmitters with a built-in mortality switch and expanding collar (Televilt AB). The use of VHF transmitters was abandoned after this initial period as the few data acquired did not justify the expense.

The captive breeding station was approved as an experimental research unit by the Norwegian Animal Research Authority. A veterinarian was responsible for any treatment of ill or injured animals. Handling of the breeding stock was kept at a minimum to avoid inflicting stress. All sides of the breeding station were marked with no admittance signs and a strict protocol for visitors was practised to avoid stress, diseases and habituation to humans.

\section{Genetic issues}

In a breeding programme, genetic variation among the founders should be as high as possible (Kalinowski et al. 2000; Rollinson et al. 2014). There is also an increasing awareness of selection effects in captivity, resulting in reduced fitness of captive-born individuals when introduced into the wild (Araki et al. 2007; Christie et al. 2012). Possible negative genetic effects within our captive breeding programme include: (1) inbreeding as an effect of a small number of founders; (2) rapid domestic selection that could have negative impacts on the fitness of released individuals; (3) adaptations that influence parental teaching of offspring; and (4) assortative mating, i.e., captive-bred foxes would prefer other captive-bred foxes as mates (Slade et al. 2014).

We founded our breeding stock from as many of the remaining small populations in Scandinavia as possible, and paired individuals expected to be unrelated to avoid the negative effects of inbreeding and to optimize genetic variation. Because of the initially small remnant population sizes of the sources for the breeding stock, we neglected, to some degree, the maintenance of possible local adaptations. However, Arctic foxes across the whole of Fennoscandia could be viewed as originally belonging to a single population (Dalén et al. 2006). To minimize the selective effect of captivity we established protocols for replacement within the breeding stock so that any single founder line did not exceed three generations in captivity, and practised a combination of recruiting new breeding individuals from the wild and from our own production. In 2015, the breeding stock of 16 animals descended from 15 founders, and the average number of generations in captivity for the breeding lines was only 0.93 , after 10 years of captive breeding. When new founders were chosen from descendants of animals released into the wild, we defined them as having zero generations in captivity after two generations in the wild.

\section{Selection of release areas}

Alpine areas and sites for release trials were identified after a thorough GIS analysis of environmental and demographic factors (Landa et al. 2006; Herfindal et al. 2010). Time since local extinction, number of old intact Arctic fox dens, height asl (avoiding low altitude areas invaded by red fox), logistical aspects (such as access) and guidelines given by the advisory group formed the scientific basis for prioritizing among areas (Supplementary Table S1), whereas the management authority-the Norwegian Environment Agency-made the final decision. Within selected areas, a combination of local knowledge, logistics and time since the last known breeding event formed the basis for choosing release sites.

\section{Release of pups}

Pups were transported from the breeding station to release sites by helicopter or a combination of road transportation and snow scooter or foot. Road 
transportation (6-24 hours) involved usage of farm fox authorized wooden individual cages, $60 \times 60 \times 60 \mathrm{~cm}$ in size, and pups were transferred to commercial portable plastic cat cages $(48 \times 32 \times 31 \mathrm{~cm})$ for short duration transportation (1-6 hours) from the end of the road to the release site. Single individuals were also put into cat carriers for helicopter transportation. The transportation method was chosen to minimize transportation time and stress for the animals. Pups were released together with siblings as whole litters at each release site at an age of eight months. Release sites were prepared close to, or on top of, old unoccupied Arctic fox dens, where an artificial den of the same kind as used in the breeding station was temporarily placed. These were removed once reoccupation and regular use of the natural den occurred. Two feeding dispensers were placed within $50-1000 \mathrm{~m}$ of the den to ensure a regular supply of food. They were placed a minimum of $400 \mathrm{~m}$ apart to avoid monopolization by single individuals. Attached to each dispenser was a Reconyx PC 800 camera-trap with a motion sensor. In addition, at geographically selected spots, a Biomark pit tag reader (HPR Plus and FS2001 models) was attached to a data logger that collected time, place and chip number. When released, the whole litter was kept within the artificial den for a few hours to acclimatize to the site. Feeding dispensers and release sites were followed up every three to four weeks by rangers from the Norwegian Environment Agency or local mountain wardens.

Recorded breedings where at least one parent originated from the captive breeding programme were followed up by trapping and marking pups during July and August. Capture and marking procedures were the same as for pups in the captive breeding facilities, with the exception that wild-born pups did not receive ear tags. We used a combination of methods to control for survival, home range use and possible dispersal to other mountain areas: (1) DNA analysis of collected faeces from which the DNA profiles are compared to the database of tissue sample DNA profiles of released and wild-born foxes; (2) chip reading (microchip) from dispensers; and (3) photographs and observations of ear-tagged foxes.

\section{Results}

\section{Failure of the initial set-up}

During the breeding season in 2002, when the first group of founders were 10 months old, no heat was observed in the females, although all males had motile sperm. Similarly in 2003, no heat was observed in the females (three of which were now 22 months old). This failure to enter oestrus was assumed to be a result of stress connected to non-optimal conditions in the captive environment. During this initial period one individual died of uncertain causes. Before the 2004 breeding season a wide range of methods were introduced to reduce stress in the farm situation. The most stressed individuals, as judged from their behaviour, were moved to a natural enclosure setting at the Langedrag animal park together with a mate. Another pair was moved to a farm where they could receive more intensive habituation. The female in the latter pair died prior to the mating season in April 2004. Furthermore, we established protocols to avoid unnecessary handling of captive individuals. We then observed immediate normalized behaviour followed by breeding success in the large enclosure at the Langedrag facility, which prompted planning for a facility with large enclosures in a natural habitat. The failed initial set-up left eight individuals (four males and four females) to be included in the new facility.

\section{Breeding success in enclosures}

Altogether, 385 pups were born in the breeding station in the period 2006-2015. In total, 59 (15\%) neonatal mortalities were recorded. Of the remaining 326 foxes that were marked during July-August, four died during autumn/early winter, one with cryptorchidism was given to a zoo, 21 pups were recruited into the breeding stock and the remaining 295 were released in seven different release areas (Tables 1, 2, Fig. 1).

In 74 breeding attempts, a litter was born in 62 cases ( $84 \%$ breeding success), with litters ranging in size from one to 14 pups, with a mean of 5.3 pups (Table 2). All foxes produced offspring, except one female and one male in a single pair (breeding attempt 2008). The breeding success of captive animals typically has a quadratic relationship with age, peaking at four years of age and decreasing at six to seven years (Landa et al. unpubl. data). Variation in mean litter size among years may be explained by effects of female age and founder line as well as random variation among pairs (Landa et al. unpubl. data).

Six of 12 failed breeding attempts involved one or more parents of non-prime age $(<2$ years or $>6$ years). In five cases, prior to breeding one or both of the parents were preyed upon by golden eagle (Aquila chrysaetos) or disappeared from the enclosure when snow drifts allowed them to escape. One breeding attempt failed when the female developed cancer. On two occasions, a second female (one of which was a sibling of the breeding male) was included in an enclosure with one male. Neither of these second females bred until moved to a new enclosure with a new male.

Neonatal mortalities included three cases of suspected infanticide (2008 and 2014), in which the entire litters disappeared, and three cases of neglected 
Table 2. Summary statistics from the captive breeding programme.

\begin{tabular}{|c|c|c|c|c|c|c|c|c|c|c|c|c|}
\hline Year & $\begin{array}{l}\text { Breeding } \\
\text { pairs }\end{array}$ & Litters & $\begin{array}{c}\text { Pups } \\
\text { marked }\end{array}$ & $\hat{0}$ & 우 & $\begin{array}{l}\text { Pups } \\
\text { released }\end{array}$ & $\begin{array}{l}\text { Adults } \\
\text { released }\end{array}$ & $\begin{array}{l}\text { Pups } \\
\text { recruited }^{\text {a }}\end{array}$ & Escaped $^{b}$ & $\begin{array}{l}\text { Neonatal } \\
\text { mortality }^{c}\end{array}$ & $\begin{array}{c}\text { Autumn } \\
\text { mortality pups }\end{array}$ & $\begin{array}{l}\text { Adult mortality within } \\
\text { enclosures }\end{array}$ \\
\hline 2006 & 4 & 1 & 6 & 3 & 3 & 2 & & 4 & & 0 & & 1 \\
\hline 2007 & 5 & 4 & 20 & 16 & 4 & 13 & & 4 & & 2 & 1 & \\
\hline 2008 & 9 & 7 & 28 & 15 & 13 & 28 & 4 & & & 12 & & 1 (euthanized) \\
\hline 2009 & 8 & 6 & 40 & 23 & 17 & 38 & & 1 & 1 & 1 & & \\
\hline 2010 & 9 & 9 & 72 & 39 & 33 & 71 & & 1 & & 1 & & \\
\hline 2011 & 9 & 8 & 42 & 19 & 23 & 40 & & 1 & 2 & 8 & 1 & 1 (euthanized) \\
\hline 2012 & 7 & 7 & 20 & 11 & 9 & 14 & & $4(1)^{d}$ & 2 & 20 & 1 & 1 (golden eagle) \\
\hline 2013 & 8 & 7 & 41 & 24 & 17 & 37 & & 2 & 1 & 5 & & 1 \\
\hline 2014 & 6 & 6 & 26 & 15 & 11 & 24 & & 2 & & 4 & & 1 (golden eagle) \\
\hline 2015 & 9 & 7 & 31 & 19 & 12 & 28 & & 2 & & 6 & 1 & \\
\hline Total & & 62 & 326 & 184 & 142 & 295 & & 21 & 6 & 59 & 4 & 6 \\
\hline
\end{tabular}

${ }^{a}$ Refers to pups recruited to the breeding stock. ${ }^{b}$ Only foxes that are later observed in the wild are accounted for as escaped. ${ }^{c}$ Counts mortalities estimated from number of pups first observed in captivity compared to number of marked pups. ${ }^{\mathrm{d}}$ Sent to Namsskogan Familiepark (a zoo), because of cryptorchidism.

care by first-year breeders. We assume that the high neonatal mortality observed during 2012 (50\%) was due to a combination of parental inexperience and environmental factors such as low temperatures with heavy precipitation and late snowmelt during the neonatal period that year. During autumn the mortality was low, with only four cases altogether (1\%, Table 2).

\section{Releases}

The first release trial was in Saltfjellet, northern Norway, when two pups from the first litter born in 2006 were released in an area still inhabited by a small remnant Arctic fox population. A non-occupied den recently used by Arctic foxes was chosen as the release site. In successive years, areas from which the Arctic fox had gone locally extinct were chosen. These were Dovrefjell (Snøhetta and Knutshø), Finse, Sylan and Hardangervidda in central and south-western Norway, and Junkeren, in northern Norway (Fig. 1). Release in Dovrefjell and Finse was terminated after five and four years, respectively, as several years of successful breeding among the released individuals had occurred and the recorded minimum spring populations were considered large enough to sustain further population growth. In Junkeren, which is a relatively small area, all initial release sites were occupied by breeding pairs during 2015. This release area has been extended towards the north-east to further bridge the gap between existing populations in Saltfjellet in Norway and Vindelfjällen across the Swedish border (Fig. 1).

\section{Feeding dispenser utilization}

Analyses based on pictures from camera-traps outside and inside the food dispensers has shown that dispensers, with few exceptions, were exclusively used by Arctic foxes (Fig. 2d). In some cases dispensers were demolished by wolverines, which also gave red foxes access to the food. Furthermore, there were a few observations of both wolverine and red foxes bringing juveniles to the dispenser, presumably because they could squeeze through the narrow tube. A camera-trap survey comparing the mountain guild visits at food dispensers to other bait stations (blocks of meat) concluded that the feeding dispensers worked exclusively for the Arctic fox (with the very few exceptions mentioned earlier) and thus reduced the intraguild competition, and in particular the competition for resources with the dominant red fox (Ertresvåg 2015).

\section{Survival and mortality causes}

A total of 243 pups born between 2006 and 2013 were released within four mountain areas (Fig. 1). A minimum of 106 released foxes (44\%) survived their first year after release. As expected, there was considerable variation in first-year survival between years, ranging from $24 \%$ for foxes born in 2013 to $71 \%$ for foxes born in 2007 and 2009. Also for the wild-born pups there was considerable variation in first-year survival between years, ranging from $0 \%$ in 2012 to $46 \%$ in 2010 , with an average of $19 \%$. The overall survival was higher for released foxes compared to foxes born in the wild, although not statistically significant $(p=0.08$, t-test; Supplementary Fig. S2).

We have very limited data on mortality causes. Foxes released in 2007 and 2008 were equipped with VHF radio collars with mortality switchers. However, only seven out of 36 collared individuals were retrieved over the following years. In addition, we collected and autopsied 12 dead Arctic foxes. The mortality cause of these 19 foxes were: nine road kills, two railroad kills, one golden eagle predation, one possible wolverine predation, one case of illegal hunting, one caught in a legal mink trap and four mortalities from unknown causes (mean distance from release site $=36.5 \mathrm{~km}, \mathrm{SD}=32.5$; Supplementary Table S2). 


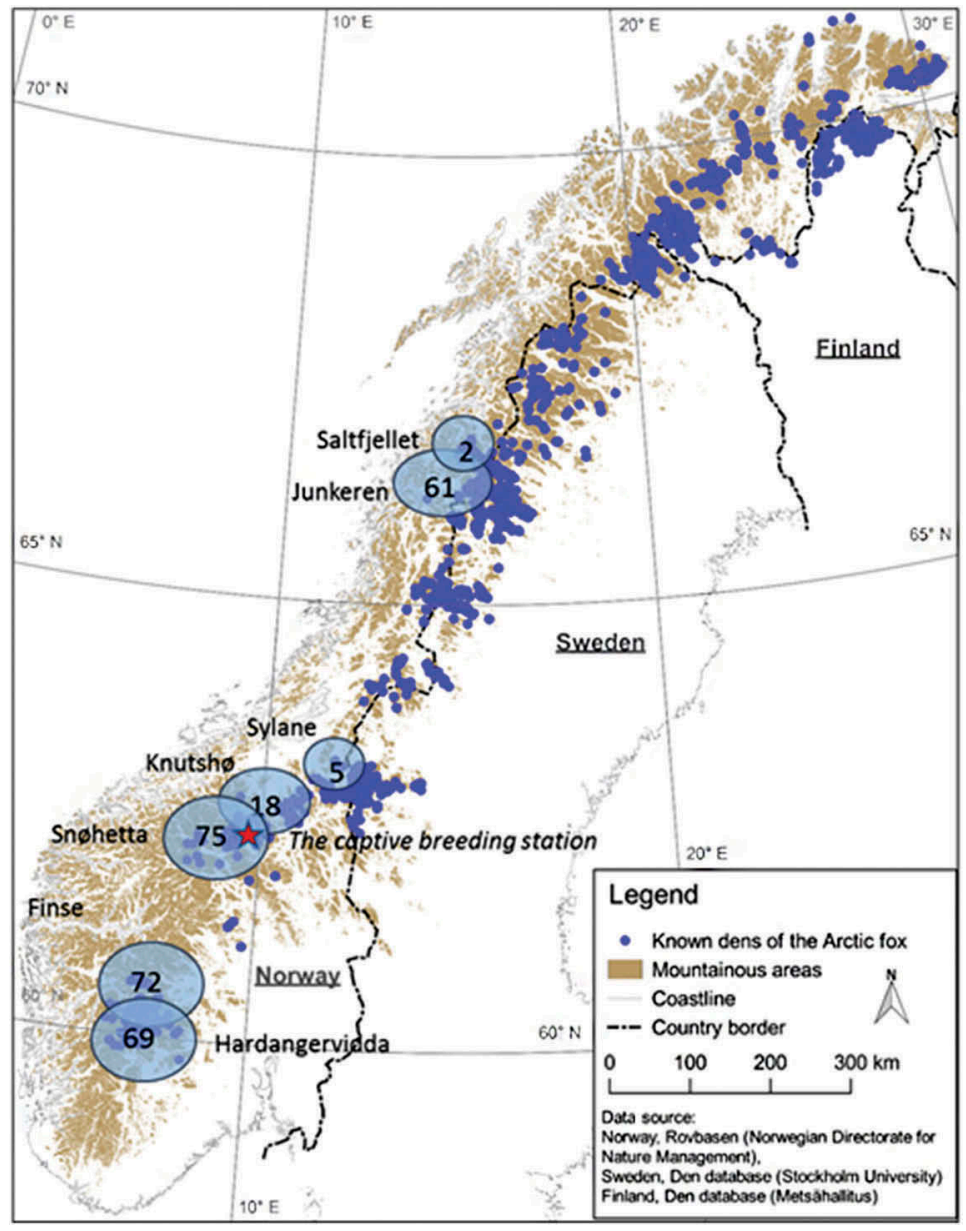

Figure 1. The geographical locations of the breeding facilities, release areas and number of pups released (Dovrefjell includes Snøhetta and Knutshø).
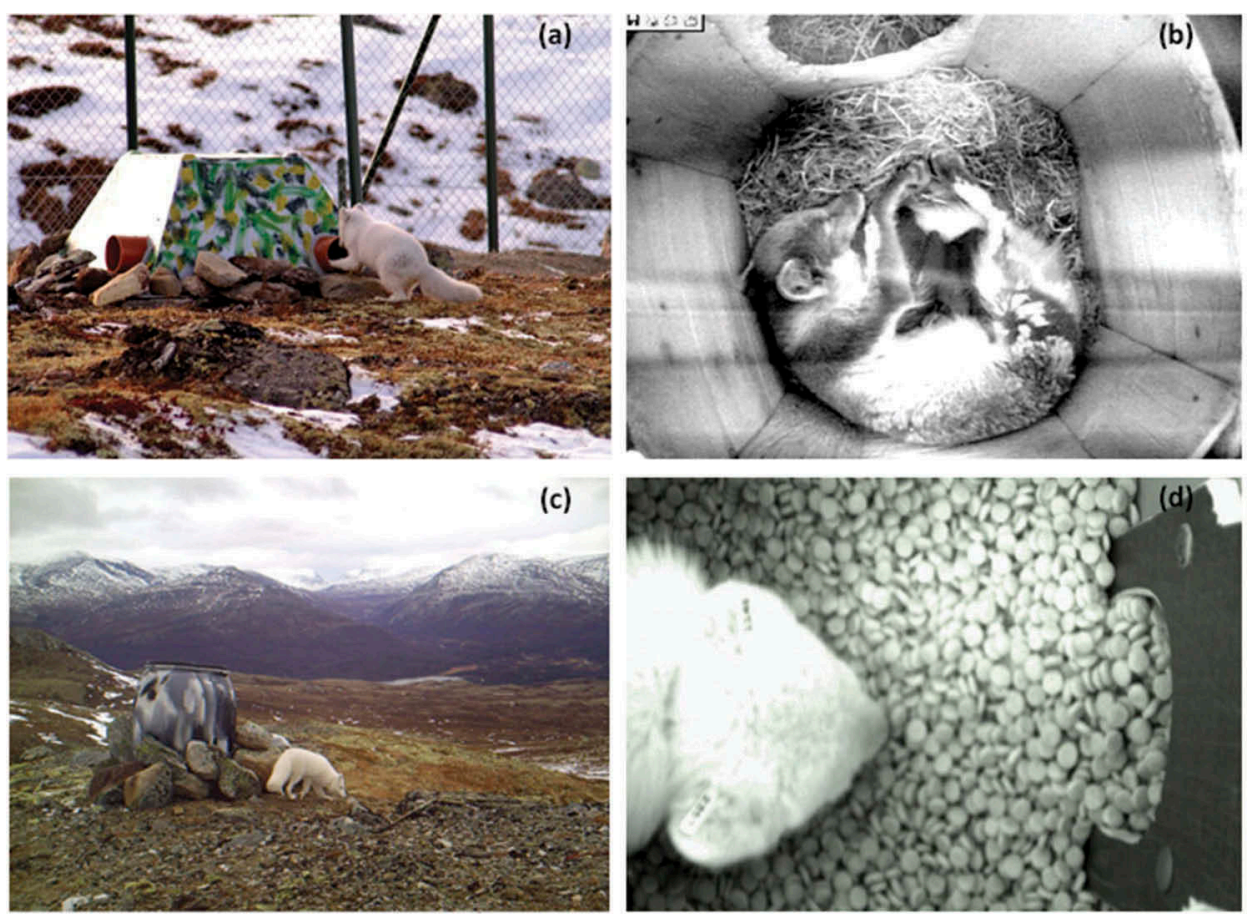

Figure 2. (a) Artificial den used within enclosures and at release sites. (b) Wooden box as seen through the monitoring system. (c) Food dispenser used within enclosures and in the release areas. (d) Arctic fox inside a feeding dispenser. 


\section{Establishment and reproduction}

In total, establishment and breeding was documented for 47 of the 267 foxes released between 2006 and 2014 (17.6\%). Of these, 39 established within the release area (mean distance from release site $=13.7 \mathrm{~km}, \mathrm{SD}=19$ and eight individuals dispersed and established in a new mountain area (mean distance from release site $=96.3 \mathrm{~km}, \mathrm{SD}=67.5)$. There was no indication of assortative mating for the released individuals, i.e., they did not seem to prefer other released individuals compared to wild-born foxes with origins in the captive breeding programme or wild foxes with no connections to the breeding programme (released $/$ released $=12$, released/wild-born $=12$ and released/'pure wild' $=15$; $n=39$ for litters where both parents were known).

During 2010-15 86 wild-born litters with parental origin in the captive breeding programme were recorded. Among these, 481 pups were captured and marked, whereas 127 were not marked (Table 3). When accounting for limitations in the national Arctic fox monitoring programme it is likely that wild-born descendants from individuals originating from the captive breeding programme have very likely exceeded 600 . Successful establishment and breeding has been documented in 18 out of 235 marked wild-born foxes (8\%).

\section{Dispersal and emigration}

Following release, foxes dispersed widely and were recorded at other release sites in the same mountain

Table 3. Arctic fox litters and pups born in the wild in different mountain areas with at least one parent originating from the Arctic fox captive breeding programme during 2010-2014.

\begin{tabular}{|c|c|c|c|c|}
\hline Year & Mountain area & Litters & Pups marked & Pups unmarked \\
\hline \multirow[t]{2}{*}{2010} & Snøhetta & 5 & 37 & 2 \\
\hline & Helags & 1 & 0 & Unknown \\
\hline \multirow[t]{6}{*}{2011} & Snøhetta & 12 & 89 & \\
\hline & Knutshø & 1 & 4 & 1 \\
\hline & Finse & 1 & 3 & \\
\hline & Saltfjellet & 1 & 0 & 8 \\
\hline & Helags $^{\mathrm{a}}$ & 3 & 41 & 11 \\
\hline & Vindelfjällen $^{\mathrm{a}}$ & 4 & 0 & 36 \\
\hline 2012 & Snøhetta & 1 & 4 & \\
\hline \multirow{4}{*}{2013} & Snøhetta & 14 & 96 & \\
\hline & Knutshø & 1 & 5 & \\
\hline & Finse & 4 & 8 & 3 \\
\hline & Helags $^{a}$ & 4 & 0 & 18 \\
\hline \multirow[t]{7}{*}{2014} & Finse & 4 & 35 & 1 \\
\hline & Saltfjellet & 1 & 6 & 1 \\
\hline & Junkeren & 1 & 4 & 3 \\
\hline & Snøhetta & 14 & 100 & 3 \\
\hline & Knutshø & 4 & 25 & 3 \\
\hline & Vindelfjällen $^{a}$ & 1 & 5 & \\
\hline & Helags ${ }^{a}$ & 1 & 6 & \\
\hline \multirow[t]{5}{*}{2015} & Snøhetta & 1 & & 4 \\
\hline & Finse & 3 & 13 & 0 \\
\hline & Saltfjellet $^{\mathrm{b}}$ & 2 & & 22 \\
\hline & Junkeren ${ }^{b}$ & 2 & & 10 \\
\hline & Total & 86 & 481 & 127 \\
\hline
\end{tabular}

${ }^{\mathrm{a}}$ In Sweden. ${ }^{\mathrm{b}}$ These breedings were assumed to have at least one parent originating from the breeding programme because at least one of the adults was observed with eartags. area. We also documented emigration to other mountain areas for several of the released foxes (average dispersal distance is $124.5 \mathrm{~km}, \mathrm{SD}=67.6, n=12$, range: 37.9-232.6; Supplementary Table S3). Because we did not have a monitoring system to detect all movements, the recorded dispersals were limited to areas where we had camera-traps and transponder readers and/or where DNA analysis from scat samples for individual identification was routinely collected outside these areas. We were dependent on observations of ear-marked foxes by the public and within the framework of the National Arctic Fox Monitoring Programme, and also from ongoing Arctic fox research projects in Sweden. The proportion of emigrants in released captive-born foxes as recorded by successful breeding during 2007-2013 was $7 / 44(16 \%)$, while emigrants among wild-born foxes originating in the breeding programme were $2 / 17$ (12\%).

\section{Discussion}

\section{Initial failures of captive breeding}

Arctic foxes have been kept in captivity for experimental and commercial purposes prior to this study (Rudzinski et al. 1982; Wakely \& Mallory 1988; Kullberg \& Angerbjörn 1992; Frafjord 1993, 1994). Our first set-up was based on a wealth of experience in the fox farming industry, which uses a form of Arctic fox that has undergone decades of artificial selection (Pedersen \& Jeppesen 1990; Pedersen 1991; Farstad et al. 1992; Farstad, Krogenæs et al. 1993; Farstad, Hyttel et al. 1993; Moe 1996). Using raised netting cages would have allowed maintenance of a large number of individuals, including easy handling for health inspection and possibly the use of artificial insemination, and might also have reduced the risk of infection compared to cage in contact with the ground. However, given the immediate response in normalized behaviour and successful breeding after moving the wild-caught Arctic foxes into a facility with large enclosures situated within the natural range of the species, and reducing handling to a minimum, it is reasonable to conclude that the initial set-up failed because of stress. The wild-caught foxes were simply not adapted to modern fox farm caging. Stress is a well-known problem in farmed foxes and, despite extensive research in enclosure design and handling protocols (Pedersen et al. 2002; Pedersen et al. 2004), it cannot be eliminated even from domesticated animals.

Many captive breeding programmes face criticism from the public. After four years of failure, there was considerable controversy around the programme, and whether it could be justified to continue collecting pups from the small remnant populations in the wild 
to fill up the new breeding facilities and replace escapees and aged individuals. However, the criticism gradually abated when the programme started to deliver pups for reintroduction to the wild. In our experience, one of the key factors to gain confidence among special interest groups and the public is to have an open and proactive information strategy at all stages of the project, continuously reporting failures and success.

\section{Breeding success in more natural Arctic fox conditions}

Our programme provided the first captive breeding facility for Arctic foxes built exclusively for conservation purposes. The immediate success in the facility within natural habitat, and a total production of 62 litters out of 74 attempts (84\%), can be attributed to careful planning and incorporating state-of-the-art methods from similar projects for related species (Smeeton et al. 2003; Coonan et al. 2005). However, not every practical detail could be foreseen, especially when constructing facilities in mountainous areas and often challenging weather conditions. Hence, many adjustments were made along the way, e.g., enlarging spaces between enclosures to reduce snow accumulation and thereby avoiding the escape of valuable breeders. Furthermore, we had to improve the foundations beneath the artificial dens as a precaution against infrequent extreme conditions, such as the extremely wet conditions in 2012 that, together with the late snowmelt, probably contributed to high neonatal mortality.

Ten years of breeding produced 385 pups, with a great annual variation in the total number of pups produced per year (6-73 pups). Several factors explain this variation, such as the number of breeding pairs, age and possible inherent differences in quality among founder lines in addition to random variance. Improvement in annual breeding success is achieved by replacing overaged foxes (six to eight years of age) with younger breeders and balancing replacements evenly over years. Avoiding habituation and other possible negative effects of captive breeding appears to be important, and it has also been important to focus on this issue within the framework of the replacement plan. As a result, the average number of generations in captivity for the breeding lines is still low after 10 years of breeding (0.93).

An earlier attempt to captive breed wild-caught Arctic foxes at Nordens Ark Zoo in Sweden failed because of disease. These foxes were kept in enclosures with natural vegetation in a close to sea level habitat in south-western Sweden more than $450 \mathrm{~km}$ from the natural range of this species. While the exact nature of this disease has never been identified, it has been speculated that it could have been transmitted through contact with the ground (Kullberg \& Angerbjörn 1992; Berg et al. 2007; Widén et al. 2012). The juxtaposition with diverse species and exposure to contact with zoo visitors are other potential source of diseases (Snyder et al. 1996), and for this reason captive breeding programmes for endangered animals should ideally maintain the target species in a minimum of two separate and isolated single-species facilities, preferably within the species' natural range (Ashton \& Cooper 1989; Snyder et al. 1996). We managed to raise funding to build only one breeding facility, but as a precaution against contagious diseases we introduced strict protocols and control of admittance for visitors. Also, the low temperatures of the high alpine habitat and the facility's remote location at the end of a mountain road probably reduced the risks of infections and disease transmission.

\section{The success of re-establishing Arctic fox populations}

Between 2007 and 2015 a total of 295 cubs were released in the wild. On average, a minimum firstyear survival of $44 \%$ was recorded. Altogether, a minimum of 47 have established and reproduced in the wild. A key factor in any captive breeding programme is thorough planning before initiating release (Snyder et al. 1996). Access to historic monitoring data (activity at known den sites, records of litters and litter size) allowed us to identify what factors were most important for successful reproduction and population persistence, further assigning habitat quality indexes both at the level of mountain fragments and at the level of each known den site within mountain fragments (Herfindal et al. 2010; Supplementary Table S1). We observed that released foxes found and re-occupied old den sites, very often dens where reproduction had been documented to have occurred in historical times. Den site quality-how well it is protected against weather and predators-was likely important for successful reproduction.

An important prerequisite for successful reintroduction programmes is the identification and elimination of the original cause of decline. Even though the threat of over-exploitation was lowered for the Fennoscandian Arctic fox populations when the fur industry shifted from wild harvest to farms at the beginning of the 1900s and appropriate legislation was introduced more than 85 years ago, the Scandinavian population is still threatened (Wiig et al. 2015). The current main threats are the small size of the population and its fragmented state, reduced food availability due to the disruption of rodent cycles, and increased competition with the larger red fox (Loison et al. 2001; Ims \& Fuglei 2005; Herfindal et al. 2010; Angerbjörn et al. 2013). 
Theory suggests that introduction (in this case reintroduction) of a species to an area often fails when a species with a similar niche already exists in the area (Elton 1946). As well as being close relatives, the Arctic fox and the red fox are both generalists with overlapping diets (Elmhagen et al. 2002). It has been shown that red foxes can displace Arctic foxes through competitive exclusion from an area just by their presence, which causes Arctic foxes to avoid the area (Tannerfeldt et al. 2002). Furthermore, the dampening of small rodent population cycles that has taken place throughout Europe (Cornulier et al. 2013) and the absence of population peaks of Norwegian lemmings in some regions (Angerbjörn et al. 2001; Henden et al. 2009) are expected to have substantial negative effects on predators like the Arctic fox, which are adapted to these fluctuating resources. The challenge for the captive breeding programme in release areas was therefore to ensure food supply for the Arctic fox and at the same time reduce food competition with the red fox.

It has been claimed that supplementary feeding cannot be carried out without controlling the red fox population (Angerbjörn et al. 2002). However, culling of red foxes is controversial and management authorities are reluctant to apply this action. It follows that an ideal solution would be a feeding strategy that does not support the red fox. By utilizing the naivety of Arctic foxes and their smaller body size compared to the bigger (and more wary) red foxes (which are also very shy of humans and human artefacts) we constructed and tested a food dispenser with a narrow tube entrance that (with insignificant exceptions) exclusively admitted Arctic foxes. Using this dispenser, we reduced the impact of intraguild competition and decreased the variation in food availability for the Arctic fox (Ertresvåg 2015).

Release of foxes was always supported with feeding dispensers in close vicinity to the release sites. The released foxes were accustomed to the dispensers from the enclosures, and we observed that the dispensers were frequently used both by released and wild-born Arctic foxes, although less in years when rodents are abundant. Comparing reproductive output and survival on fed and non-fed den sites, supplementary feeding has proved to impact the number of litters, litter size and early pup survival (Tannerfeldt et al. 1994; Angerbjörn et al. 2013; Meijer et al. 2013). Trials to explore a population's response to reduced subsidies once re-established have not yet been carried out.

We have been able to re-establish the Arctic fox population in three mountain areas without controlling the red foxes in these areas. Although many studies have claimed that Arctic foxes cannot survive where red foxes occur on a permanent basis (Hersteinsson et al. 1989; Frafjord 2003; Hamel et al. 2013), this is not yet fully understood. An alternative hypothesis would be that a larger Arctic fox population might have more resistance to being displaced by red foxes.

\section{Survival, establishment and dispersal}

The recorded first-year survival of released captiveborn individuals as compared to wild-born foxes indicates that released individuals performed well. Estimates of Arctic fox first-year survival are very scarce in the literature. However, it is known that the juvenile mortality rate due to starvation and predation can reach more than $90 \%$ in some years (Meijer et al. 2008), depending on the phase of the rodent cycle. In comparison, the lowest minimum first-year survival among the released foxes was $31 \%$, recorded for the 2008 cohort, which indicates a much lower mortality for the released foxes than documented by Meijer et al. (2008).

One possible explanation could be that the foxes have been released in January-February. Juvenile mortality is highest during autumn whereas winter mortality does not differ significantly between adults and juveniles (Meijer et al. 2008). Although not directly comparable, it seems evident that the released foxes generally were in very good body condition, at a time when wild foxes have started to subsist on their body fat reserves. The mean weight of the foxes at release in January/February was $3985 \mathrm{~g}(\mathrm{SE}= \pm 37$, $n=250$; Landa et al. unpubl. data), compared to wildliving adult foxes trapped in March from the same areas: $3590 \mathrm{~g}$ ( $\mathrm{SE}= \pm 70, n=34$; Landa et al. unpubl. data). It follows that released foxes probably do not suffer starvation during the harshest winter time.

The scarce data on the mortality causes of released foxes reveals that road and railroad killings are by far the most prevalent causes of death in released individuals (58\%). Railways and roads commonly attract foxes and other scavenging carnivores because they are a potential source of food. However, the number of traffic fatalities may be biased: most road kills of a rare species like the Arctic fox are reported and therefore recorded, whereas only a limited number of other deaths were documented.

Being born in enclosures placed in a natural habitat has probably also given the foxes a chance to adopt natural behaviour. We have documented attacks and even predation from golden eagles within the captive breeding facility. The area outside the enclosures are frequently also visited by both red foxes and wolverines, which can occasionally prey on the Arctic fox (Frafjord et al. 1989; Tannerfeldt et al. 2002). Indeed, we have observed foxes making warning calls at the approach of a potential predator to an enclosure-anti-predator behaviour that pups 
may learn. The pups also have access to some natural food as rodents pass through the wire fences.

In populations with a natural density, Arctic foxes display enormous dispersal capability. At a circumpolar scale Norén et al. (2011) showed that there was some degree of genetic connectivity between sites separated up to $2000 \mathrm{~km}$ apart. In fact, dispersal distances of more than $4000 \mathrm{~km}$ have been documented (Tarroux et al. 2010). For a species like the Arctic fox in Scandinavia, living in fragmented habitats and relying on fluctuating and partly asynchronous prey resources, dispersal and settlement of immigrants may be the key to population persistence (Loison et al. 2001). Dalén et al. (2006) showed that the remaining Scandinavian population was structured into four genetically distinct subpopulations. The released foxes from the captive breeding programme increased the connectivity between subpopulations. Nine cases of successful emigrants were documented, every single dispersal event providing valuable genetic variation. Release of foxes (of mixed origins) in extant populations also counteracts the loss of genetic diversity.

\section{Conclusions and future prospects}

The Arctic fox captive breeding programme in its present form has within a few years proven to be the most efficient conservation action to re-establish and strengthen populations of the critically endangered Arctic fox in Scandinavia. Within 10 years, successful breeding in captivity and effective release methods have been established.

Three mountain areas where Arctic foxes formerly existed have so far been recolonized, and one of them has become the largest Arctic fox population in continental Norway. In fact, after only seven years of release, $50 \%$ of all reproductions documented in the wild $(n=50)$ originated from foxes released from the captive breeding programme (Rød-Eriksen et al. 2014). Other populations, including populations in neighbouring Sweden, have benefited considerably from immigrants dispersing from the release sites. Recorded minimum numbers of wild-born pups, with one or more parents originating from the captive breeding programme, has likely reached more than 600 wild-born pups.

The Arctic fox captive breeding programme, financed by the environmental authorities in Norway, will continue to re-establish and strengthen Arctic fox populations in Fennoscandia (Norwegian Environment Agency 2017). In the last few years we have focused on re-establishing Arctic foxes at Hardangervidda (2013-16) in southern Norway, and we are preparing an eight-year release programme at the Varanger Peninsula in northernmost Norway, starting in 2018, in collaboration with the University of Tromsø. In the European Union cross-border project Arctic Fox Together, we will also start discussing a cross-border release programme in northern Sweden and Finland.

In the years to come, a priority for the Arctic fox captive breeding programme will be a continuous effort to improve the monitoring of survival and reproduction of released individuals. We will also test the effects of a reduced artificial supply of food. Furthermore, we need a better understanding of the relationship between the Arctic fox and the red fox, whether a dense Arctic fox population is more resistant to displacement by the red fox. Finally, assessment of the success of released individuals of different colour morphs (blue and white) may offer unique insights into the Arctic fox's ability to adapt to changes in snow cover as the climate changes.

\section{Acknowledgements}

We are grateful for the valuable assistance provided by the many field workers, professionals, students and volunteers who throughout each of the 10 years reported here have spent many days in the field to mark pups, maintain food supply and collect data from cameras and loggers. We also thank our technicians Roger Meås, Roy Andersen, Toralf Mjøen, Tommy Sandalen and Haldor Haugland. The genetic laboratory work was skillfully conducted by Torveig Balstad, Line Birkeland Eriksen, Merethe Spets, Line Syslak and Caroline Danielsen Søgaard.

\section{Disclosure statement}

No potential conflict of interest was reported by the authors.

\section{Funding}

This work was supported by the Norwegian Environment Agency.

\section{References}

Angerbjörn A., Eide N.E., Dalén L., Elmhagen B., Hellström P., Ims R.A., Killengreen S., Landa A., Meijer T., Mela M., Niemimaa J., Norén K., Tannerfeldt M., Yoccoz N.G., Henttonen H. \& Pettorelli N. 2013. Carnivore conservation in practice: replicated management actions on a large spatial scale. Journal of Applied Ecology 50, 59-67.

Angerbjörn A., Tannerfeldt M., Henttonen H., Elmhagen B. \& Dalen L. 2002. Bevarande av fjällräv Alopex lagopus $i$ sverige og finland. Sverige: Stockholms universitet.

Angerbjörn A., Tannerfeldt M. \& Lundberg H. 2001. Geographical and temporal patterns of lemming population dynamics in Fennoscandia. Ecography 24, 298-308.

Araki H., Cooper B. \& Blouin M.S. 2007. Genetic effects of captive breeding cause a rapid, cumulative fitness decline in the wild. Science 318, 100-103.

Ashton W.L.G. \& Cooper J.E. 1989. Exclusion, elimination and control of avian pathogens. In J.E. Cooper (ed.): 
Disease and threatened birds. Pp. 31-38. Cambridge: International Council for Bird Preservation.

Beck B.B., Rapaport L.G., Stanley Price M.R. \& Wilson A.C. 1994. Reintroduction of captive-born animals. In P.J.S. Olney et al. (eds.): Creative conservation: interactive managment of wild and captive animals. Pp. 265-286. London: Chapman \& Hall.

Berg A.-L., Gavier-Widén D., Nilsson K., Widén F., Berg M., Gregorius S., Agren E., Erlandsson M. \& Mörner T. 2007. Necrotizing encephalitis of unknown cause in Fennoscandian Arctic foxes (Alopex lagopus). Journal of Veterinary Diagnostic Investigation 19, 113-117.

Carbyn L.N., Armbruster H.J. \& Mamo C. 1994. The swift fox reintroduction program in Canada from 1983 to 1992. In M.L. Bowles \& C.J. Whelan (eds.): Restoration of endangered species. Pp. 247-271. Cambridge: Cambridge University Press.

Ceballos G. \& Ehrlich P.R. 2002. Mammal population losses and the extinction crisis. Science 296, 904-907.

Christie M.R., Marine M.L., French R.A. \& Blouin M.S. 2012. Genetic adaptation to captivity can occur in a single generation. Proceedings of the National Academy of Sciences of the United States of America 109, 238-242.

Collett R. 1912. Norges pattedyr. (Mammals of Norway.) Kristiania: H. Aschehaug \& Co.

Coonan T.J., Schwemm C.A., Roemer G.W., Garcelon D.K. \& Munson L. 2005. Decline of an island fox subspecies to near extinction. The Southwestern Naturalist 50, 32-41.

Cornulier T., Yoccoz N.G., Bretagnolle V., Brommer J.E., Butet A., Ecke F., Elston D.A., Framstad E., Henttonen H., Hörnfeldt B., Huitu O., Imholt C., Ims R.A., Jacob J., Jędrzejewska B., Millon A., Petty S.J., Pietiäinen H., Tkadlec E., Zub K. \& Lambin X. 2013. Europe-wide dampening of population cycles in keystone herbivores. Science 340, 63-66.

Dalén L., Gotherstrom A., Tannerfeldt M. \& Angerbjorn A. 2002. Is the endangered Fennoscandian Arctic fox (Alopex lagopus) population genetically isolated? Biological Conservation 105, 171-178.

Dalén L., Kvaløy K., Linnell J.D.C., Elmhagen B., Strand O., Tannerfeldt M., Henttonen H., Fuglei E., Landa A. \& Angerbjörn A. 2006. Population structure in a critically endangered Arctic fox population: does genetics matter? Molecular Ecology 15, 2809-2819.

Davis M.H. 1983. Post-release movements of introduced marten (Martes americana, Wisconsin). The Journal of Wildife Management 47, 59-66.

Elmhagen B., Tannerfeldt M. \& Angerbjörn A. 2002. Foodniche overlap between Arctic and red foxes. Canadian Journal of Zoology 80, 1274-1285.

Elton C.S. 1946. Competition and the structure of ecological communities. The Journal of Animal Ecology 15, 54-68.

Ertresvåg I. 2015. Arctic fox (Vulpes lagopus) use of feeding dispensers and bait stations in central Norway: impact of intra-guild competition and rodent abundance. Master's thesis, Norwegian University of Life Sciences, Ås.

Farstad W., Hyttel P., Grøndahl C., Mondain Monval M. \& Smith A.J. 1993. Fertilization and early embryonic development in the blue fox (Alopex lagopus). Molecular Reproduction and Development 36, 331-337.

Farstad W., Krogenæs A., Nagyov E., Hafne A.L. \& Hyttel P. 1993. In vitro techniques in fox reproduction. Livestock Production Science 36, 23-27.

Farstad W.K., Fougner J.A. \& Andersen Berg K. 1992. Species differences in fertility after artifical insemination with frozen semen in fox pure breeding. Norwegian Journal of Agricultural Science Supplement 9, 115-121.
Frafjord K. 1993. Food habits of Arctic foxes (Alopex lagopus) on the western coast of Svalbard. Arctic 46, 49-54.

Frafjord K. 1994. Døgnaktivitet hos fjellrev i bur på Svalbard. (Daily activity of Arctic foxes in cages in Svalbard.) Fauna 47, 236-241.

Frafjord K. 2003. Ecology and use of Arctic fox Alopex lagopus dens in Norway: tradition overtaken by interspecific competition? Biological Conservation 111, 445-453.

Frafjord K., Becker D. \& Angerbjörn A. 1989. Interactions between Arctic and red foxes in Scandinavia - predation and aggression. Arctic 42, 354-356.

Fritts S.H., Paul W.J. \& Mech L.D. 1985. Can relocated wolves survive? Wildlife Society Bulletin 13, 459-463.

Garrott R.A. \& Eberhardt L.E. 1982. Mortality of Arctic fox pups in northern Alaska. Journal of Mammalogy 63, 173-174.

Ginsberg J.R. 1994. Captive breeding, reintroduction and the conservation of canids. In P.J.S. Olney et al. (eds.): Creative conservation: interactive managment of wild and captive animals. Pp. 365-383. London: Chapman \& Hall.

Griffith B. \& Scott J.M. 1993. Animal translocation and potential disease transmission. Journal of Zoo and Wildlife Medicine 24, 2231-2236.

Griffith B., Scott J.M., Carpenter J.W. \& Reed C. 1989. Translocation as a species conservation tool: status and strategy. Science 245, 477-480.

Hamel S., Killengreen S. T., Henden J. A., Yoccoz N. G., \& Ims R. A. 2013. Disentangling the importance of interspecific competition, food availability, and habitat in species occupancy: recolonization of the endangered Fennoscandian Arctic fox. Biological Conservation 160, 114-120.

Henden J., Ims R. \& Yoccoz N. 2009. Nonstationary spatiotemporal small rodent dynamics: evidence from longterm Norwegian fox bounty data. The Journal of Animal Ecology 78, 636-645.

Herfindal I., Linnell J.D.C., Elmhagen B., Andersen R., Eide N.E., Frafjord K., Henttonen H., Kaikusalo A., Mela M., Tannerfeldt M., Dalén L., Strand O., Landa A. \& Angerbjörn A. 2010. Population persistence in a landscape context: the case of endangered Arctic fox populations in Fennoscandia. Ecography 33, 932-941.

Hersteinsson P., Angerbjorn A., Frafjord K., \& Kaikusalo A. 1989. The Arctic fox in Fennoscandia and Iceland: management problems. Biological Conservation 49, 67-68.

Ims R. \& Fuglei E. 2005. Trophic interaction cycles in tundra ecosystems and the impact of climate change. BioScience 55, 311-322.

IUCN (International Union for Conservation of Nature) 2009. Arctic foxes and climate change. Outfoxed by Arctic warming. Cambridge, UK: IUCN Global Species Programme Red List Unit.

Jefferies D.J., Wayre P., Jessop R.M. \& Mitchell-Jones A.J. 1986. Reinforcing the native otter Lutra lutra population in East Anglia: an analysis of the behaviour and range development of the first release group. Mammal Review $16,65-79$.

Jule K.R., Leaver L.A. \& Lea S.E.G. 2008. The effects of captive experience on reintroduction survival in carnivores: a review and analysis. Biological Conservation 141, 355-363.

Kalinowski S.T., Hedrick P.W. \& Miller P.S. 2000. Inbreeding depression in the Speke's gazelle captive breeding program. Conservation Biology 14, 1375-1384.

Kleiman D.G. 1989. Reintroduction of captive mammals for conservation: guidelines for reintroducing endangered species into the wild. BioScience 39, 152-161. 
Kullberg C. \& Angerbjörn A. 1992. Social behaviour and cooperartive breeding in Arctic foxes, Alopex lagopus (L.), in a semi natural environment. Ethology 90, 321-335.

Landa A., Eide N.E., Flagstad Ø., Herfindal I., Strand O., Andersen R., van Dijk J., Kvaløy K. \& Linnell J.D.C. 2006. Bevaringsbiologi - fjellrev i NINA 2006. (Conservation biology - Arctic foxes in NINA 2006.) NINA Rapport 214. Trondheim: Norwegian Institute for Nature Research.

Linnell J.D.C., Aanes R., Swenson J.E., Odden J. \& Smith M.E. 1997. Translocation of carnivores as a method for managing problem animals: a review. Biodiversity and Conservation 6, 1245-1257.

Linnell J.D.C., Strand O., Loison A., Solberg E.J. \& Jordhøy P. 1999. A future for the Arctic fox in Norway? A status report and action plan. NINA Oppdragsmelding 576. Trondheim: Norwegian Institute for Nature Research.

Loison A., Strand O. \& Linnell J.D.C. 2001. Effect of temporal variation in reproduction on models of population viability: a case study for remnant Arctic fox (Alopex lagopus) populations in Scandinavia. Biological Conservation 97, 347-359.

Lönnberg E. 1927. Fjällrävstammen i Sverige 1926. (Arctic fox population in Sweden, 1926.) Kungliga Svenska Vetenskapsakademiens Skrifter i Naturskyddsärenden 7. Uppsala: Royal Swedish Academy of Sciences.

Meijer T., Elmhagen B., Eide N.E. \& Angerbjörn A. 2013. Life history traits in a cyclic ecosystem: a field experiment on the Arctic fox. Oecologia 173, 439-447.

Meijer T., Norén K., Hellström P., Dalén L. \& Angerbjörn A. 2008. Estimating population parameters in a threatened Arctic fox population using molecular tracking and traditional field methods. Animal Conservation 11, 330-338.

Moe R.O. 1996. Investigation of methods to assess stress in farmed silver foxes (Vulpes vulpes). $\mathrm{PhD}$ dissertation, Norwegian College of Veterinary Medicine, Oslo.

Mørk T. \& Prestrud P. 2001. Rabies i arktiske områder, aktualitet for Norge. (Rabies in the Arctic region, potential in Norway.) Norsk Veterinortidsskrift 113, 361-367.

Norén K., Carmichael L., Fuglei E., Eide N.E., Hersteinsson P., \& Angerbjörn A. 2011. Pulses of movement across the sea ice: population connectivity and temporal genetic structure in the Arctic fox. Oecologia 166, 973-984.

Norwegian Environment Agency. 2017. Handlingsplan for fjellrev. Norge - Sverige. 2017-2021. (Action plan for Arctic fox Norway - Sweden. 2017-2021.) Oslo: Norwegian Environment Agency.

Østbye E., Skar H.J., Svalastog D. \& Westby K. 1978. Fjellrev og rødrev på Hardangervidda; hiøkologi, utbredelse og bestandsstatus. (Arctic fox and red fox in Hardangervidda: den ecology, distribution and population status.) Meddelelser fra Norsk Viltforskning 3. Trondheim: Norwegian Institute for Nature Research.

Pedersen V. 1991. Early experience with the farm environment and effects on later behaviour in silver Vulpes vulpes and blue foxes Alopex lagopus. Behavioural Processes 25, 163-169.

Pedersen V. \& Jeppesen L.L. 1990. Effects of early handling on later behaviour and stress responses in the silver fox (Vulpes vulpes). Applied Animal Behaviour Science 26, 383-393.

Pedersen V., Jeppesen L.L. \& Jeppesen N. 2004. Effects of group housing systems on behaviour and production performance in farmed juvenile mink (Mustela vison). Applied Animal Behaviour Science 88, 89-100.

Pedersen V., Moeller N.H. \& Jeppesen L.L. 2002. Behavioural and physiological effects of post-weaning handling and access to shelters in farmed blue foxes
(Alopex lagopus). Applied Animal Behaviour Science 77, 139-154.

Phillips M.K. \& Parker W.T. 1988. Red wolf recovery: a progress report. Conservation Biology 2, 139-141.

Phillips M.K., Smith R., Henry V.G. \& Lucash C. 1995. Red wolf reintroduction program. In L.N. Carbyn et al. (eds.): Ecology and conservation of wolves in a changing world. Pp. 157-168. Edmonton: Canadian Cirumpolar Institute.

Prestrud P., Krogsrud J. \& Gjertz I. 1992. The occurrence of rabies in the Svalbard islands of Norway. Journal of Wildlife Diseases 28, 57-63.

Rød-Eriksen L., Eide N.E., Flagstad Ø., Kleven O., Ulvund K. \& Landa A. 2014. Fjellrev i Norge 2014. Resultater fra det nasjonale overvåkingsprogrammet for fjellrev. (Arctic fox in Norway 2014. Results of the national Arctic fox monitoring programme.) NINA Rapport 1080. Trondheim: Norwegian Institute for Nature Research.

Rollinson N., Keith D.M., Houde A.L.S., Debes P.V., McBride M.C. \& Hutchings J.A. 2014. Risk assessment of inbreeding and outbreeding depression in a captivebreeding program. Conservation Biology 28, 529-540.

Rudzinski D.R., Graves H.B., Sargeant A.B. \& Storm G.L. 1982. Behavioral interactions of penned red and Arctic foxes. The Journal of Wildlife Management 46, 877-884. Servheen C., Kasworm W.F. \& Thier T.J. 1995. Transplanting grizzly bears Ursus arctos horribilis as a management tool - results from the Cabinet Mountains, Montana, USA. Biological Conservation 71, 261-268.

Slade B., Parrott M.L., Paproth A., Magrath M.J.L., Gillespie G.R. \& Jessop T.S. 2014. Assortative mating among animals of captive and wild origin following experimental conservation releases. Biology Letters 10, 20140656, doi: 10.1098/rsbl.2014.0656.

Slough B.G. 1989. Movements and habitat use by transplanted marten in the Yukon Territory. The Journal of Wildife Management 53, 991-997.

Slough B.G. 1994. Translocations of American martens: an evaluation of factors in success. In S.W. Buskirk et al. (eds.): Martens, sables, and fishers: biology and conservation. Pp. 165-178. Ithaca, NY: Cornell University Press.

Smeeton C. 1994. Reintroducing the swift fox. Canid News, 13-16.

Smeeton C., Weagle K. \& Waters S. 2003. Captive breeding of the swift fox at the Cochrane Ecological Institute, Alberta. In M.A. Sovada \& L.N. Carbyn (eds.): The swift fox - ecology and conservation of swift foxes in a changing world. Regina: Canadian Plains Research Centre, University of Regina.

Smith K.G. \& Clark J.D. 1994. Black bears in Arkansas: characteristics of a successful translocation. Journal of Mammalogy 75, 309-320.

Snyder N.F.R., Derrickson S.R., Beissinger S.R., Wiley J.W., Smith T.B., Toone W.D. \& Miller B. 1996. Limitations of captive breeding in endangered species recovery. Conservation Biology 10, 338-348.

Soderquist T.R. \& Serena M. 1994. An experimental reintroduction programme for brush-tailed phascogales (Phascogale tapoatafa): the interface between captivity and the wild. In P.J.S. Olney et al. (eds.): Creative conservation: interactive managment of wild and captive animals. Pp. 431-438. London: Chapman \& Hall.

Stanley Price M.R. 1989. Animal reintroductions: the Arabian oryx in Oman. Cambridge: Cambridge University Press.

Tannerfeldt M. \& Angerbjörn A. 1996. Life history strategies in a fluctuating environment: establishment and reproductive success in the Arctic fox. Ecography 19, 209-220. 
Tannerfeldt M. \& Angerbjörn A. 1998. Fluctuating resources and the evolution of litter size in the Arctic fox. Oikos 83, 545-559.

Tannerfeldt M., Angerbjörn A. \& Arvidson B. 1994. The effect of summer feeding on juvenile Arctic fox survival - a field experiment. Ecography 17, 88-96.

Tannerfeldt M., Elmhagen B. \& Angerbjörn A. 2002. Exclusion by interference competition? The relationship between red and Arctic foxes. Oecologia 132, 213-220.

Tarroux A., Berteaux D. \& Bêty J. 2010. Northern nomads: ability for extensive movements in adult Arctic foxes. Polar Biology 33, 1021-1026.

Wakely L.G. \& Mallory F.F. 1988. Hierarchical development, agonistic behaviours, and growth rates in captive Arctic fox. Canadian Journal of Zoology 66, 1672-1678.
Widén F., Sundström E., Gavier-Widén D., Berg A.L., Dillner B. \& Berg M. 2012. Detection of herpesvirus DNA in Arctic foxes (Vulpes lagopus; syn. Alopex lagopus) with fatal encephalitis. Research in Veterinary Science 92, 509-511.

Wiig Ø., Bjørge A., Isaksen K., Kovacs K.M., Swenson J. E. \& Syvertsen P.O. 2015. Pattedyr (Mammalia). (Mammals. [Mammalia].) In S. Henriksen \& O. Hilmo (eds.): Norsk rødliste for arter 2015. (Norwegian Red List 2015.) Trondheim: Norwegian Biodiversity Information Centre.

Woodroffe R. 2001. Strategies for carnivore conservation: lessons from contemporary extinctions. In J.L. Gittleman et al. (eds.): Carnivore conservation. Pp. 61-92. Cambridge: Cambridge University Press. 